\title{
E-Readiness of Integrated Information Systems Using STOPE Framework in Udayana University
}

\author{
Theca Difa Yulian Syahputri ${ }^{\mathrm{a} 1}$, Dwi Putra Githa ${ }^{\mathrm{a} 2}$, I Putu Agus Eka Pratama ${ }^{\mathrm{a} 3}$ \\ ${ }^{a}$ Department of Information Technology, Faculty of Engineering, Udayana University, Indonesia \\ e-mail: ${ }^{1}$ difa yulian@student.unud.ac.id, ${ }^{2}$ dwiputragitha@unud.ac.id, ${ }^{3}$ eka.pratama@unud.ac.id
}

\begin{abstract}
Abstrak
Perguruan tinggi adalah salah satu dari banyak instansi yang beralih ke sistem teknologi informasi untuk menjalannya proses bisnis dan manajemennya yang merupakan dampak dari era revolusi industri 4.0. Peralihan sistem lama ke sistem baru sering ditemukan masalah karena kurang memperhatikan e-readiness atau kesiapan teknologinya. Perlu adanya penilaian kesiapan untuk dapat meminimalisir masalah dalam penerapan sistem baru. Kerangka kerja STOPE adalah salah satu yang dapat digunakan sebagai alat penilaian kesiapan teknologi informasi di tingkat perguruan tinggi. IMISSU adalah layanan satu pintu milik Universitas Udayana yang merupakan sistem informasi manajemen yang saling terintegrasi. IMISSU berada pada tingkat sangat siap (4) berdasarkan hasil dari penilaian e-readiness dengan menggunakan kerangka kerja STOPE yang dilakukan penilaian di tiga tingkatan yaitu tingkat domain, isu dan faktor. 100 buah kuesioner disebar ke berbagai civitas yang telah disesuaikan dengan tanggung jawab yang sesuai dengan domain kerangka kerja STOPE.
\end{abstract}

Kata kunci: Sistem Informasi Terintegrasi, E-readiness, IMISSU, STOPE, Domain

\begin{abstract}
Higher education is one of the many institutions that have switched to information technology systems to carry out business processes and their management, which resulted from the era of the industrial revolution 4.0. The old system's transition to the new system is often encountered problems due to a lack of attention to the technology's readiness or readiness. It is necessary to know the readiness to be able to minimize problems in implementing the new system. The STOPE framework can be used as an information technology readiness tool at the tertiary level. IMISSU is a Single Sign-On owned by Udayana University, which is an integrated management information system. IMISSU is at the very ready level (4) based on the e-readiness results using the STOPE framework, which is carried out based on three levels: the level domain, issues, and factors. One hundred questionnaires were distributed to various defeated community members with responsibilities following the STOPE framework.
\end{abstract}

Keywords: Integrated Information System, E-readiness, , IMISSU, STOPE, Domain

\section{Introduction}

The shift in the use of digital technology by industry impacts the era of the industrial revolution 4.0. The industrial revolution 4.0 is believed to improve the quality of life and the economy significantly. Integrated information technology is one of the nine technologies that are the main pillars of the industrial revolution 4.0 [1]. An integrated system is needed to manage the business in all functional areas because it makes it easy for system managers and users in different functional areas to exchange information and data [2]. The development of integrated information technology has caused many agencies to switch to implementing an integrated information technology system as a tool to run their business processes, including higher education institutions.

The development and implementation of new systems often encounter problems because they do not pay attention to technological readiness (e-readiness), leading to suboptimal benefits from implementation or large losses. After all, building or implementing a new system requires a lot of resources. The solution to overcome this is to assess technology 
readiness (e-readiness) either before or after the new system using a framework following the agency and needs.

IMISSU is a Single Sign-On (SSO) owned by Udayana University. IMISSU is an integrated management information system that has been used by Udayana University for five years and has gone through many changes. However, the IMISSU system readiness assessment has never been conducted to determine the level of readiness. Assessment of the level of readiness can be used to identify components that substantially impact the successful implementation of IMISSU and components that are considered weak or need special attention not to become obstacles in the development of IMISSU.

One of the frameworks used in universities is the STOPE framework. The STOPE framework is flexible; it can be adapted to a case study and can be used before and after the system is implemented. STOPE Framework consists of five domains; domain strategy, domain technology, domain organization, domain people, and domain environment. [3]. STOPE assessment is carried out at three levels: the main domain level, the sub-domain (issue) level, and the sub-sub-domain (factor) level.

\section{Research Method}

The research method used in this research consists of the stages of research, data collection methods and data analysis methods.

\subsection{Research Stages}

The research stages in the outline include literature study and modification of the framework to measure higher education readiness. Arranging data collection in the form of questionnaires and surveys, which are research tools. Process and analyze data, and assess the readiness of the research object.

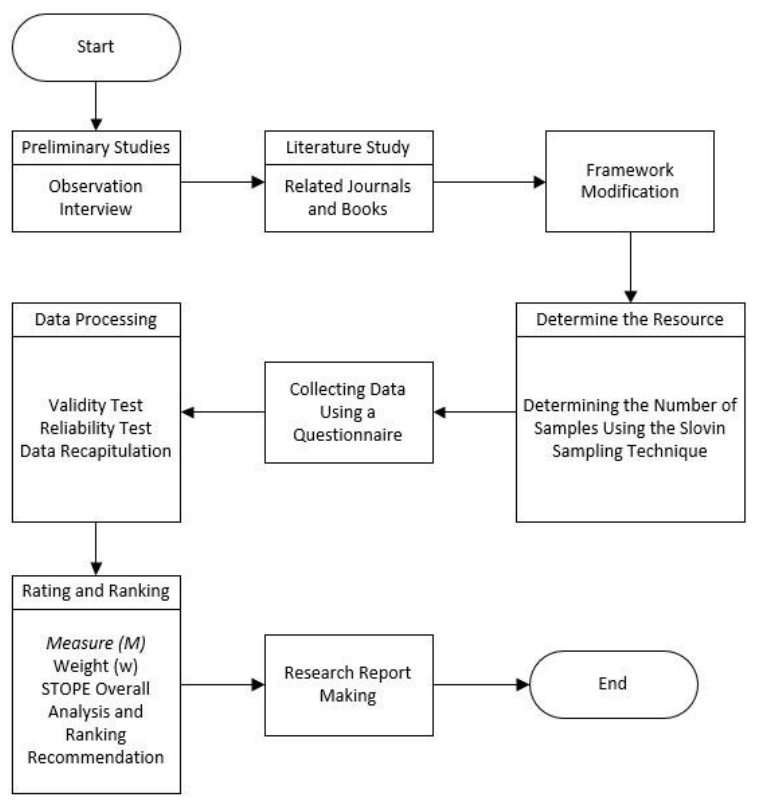

Figure 1. Research Stages

Figure 1 is an overview of the stages of the research. Starting from a literature study from previous research journals. The modified framework adapts to the case study being handled-preparation of research tools in a questionnaire. Data collection was carried out by distributing questionnaires. Process and analyze data obtained from distributing questionnaires and data assessments, and provide recommendations.

\subsection{Data Collection Methods}

Data collection methods are techniques or methods used to obtain data. The data collection method used in this research is a literature study to collect information and theories 
relevant to the case studied. Interviews and observations were conducted to obtain important information related to research not obtained through a questionnaire. Interviews were conducted with employees at the USDI office of Udayana University to find out the vision, mission, and business processes that were taking place at the agency and lead discussions on the modification of the questionnaire to achieve the right questionnaire with research. Questionnaires to get responses or ratings from research respondents. The questionnaire was divided according to the status or position of the respondents according to the related domain. Determination of the minimum research sample using the Slovin technique.

\subsection{Data Analysis Methods}

There are several data analyzes that need to be done in this study. The data analysis used was a validity test and reliability test to determine the questionnaire data's validity. Analysis of the processed data is also needed, namely an analysis for ranking data using a 4point CID scale.

\section{Literature Study}

Literature study contains state of the art from previous research and material that related to e-readiness, integrated information system and STOPE.

\subsection{State of the Art}

Similar research is related to the system readiness assessment carried out in the Gunung Kidul Regency Government to measure the readiness to accept the transfer of PBB (Land and Building Tax) from the center to the regions. The analysis results show that the Gunung Kidul Regency Government is at rank three or the ready level [4]. The equation in this study is the use of the STOPE Framework as a readiness assessment. The difference is the implementation of the readiness assessment, which is used to assess the readiness of implementing e-government

Similar research related to system readiness assessment was carried out at the Yogyakarta Tourism Academy. The study evaluated the Yogyakarta Tourism Academy's academic information system (Akparyo) using the STOPE framework. The evaluation was carried out on five main domains, 15 sub-domains (issues), and 64 sub-sub-domains (factors). Overall, the results showed that Akparyo was in the 1st rank, or the level was not ready [5]. The equation in this study is the use of the STOPE Framework as a readiness assessment. The difference is the implementation of the readiness assessment used to assess the academic information system's readiness.

The next research is research conducted at IMISSU Udayana University to evaluate the SIMDOS system belonging to Udayana University. Evaluations are carried out to assess the system's suitability to the needs of users and management at Udayana University. The evaluation uses the HOT-Fit (Human, Organization, and Technology Fit) model, modified according to the existing model in previous research. Data were collected using a questionnaire and to analyze the data using SEM (Structural Equation Model) with AMOS 18 software's help. The results showed that SIMDOS has been successfully implemented following users and management's needs at Udayana University but has not reached its maximum value [6]. The similarity of this research lies in the research subject, namely IMISSU. The difference is assessing the suitability of the system with the needs of users and management at Udayana University and using a different method, namely HOT-Fit. This research can be used as a comparison of research results.

Similar research is related to research conducted at IMISSU Udayana University, namely to evaluate to identify the performance of information technology at Udayana University to achieve its vision, mission, and objectives using COBIT 5, which focuses on the DSS Domain. The results showed that the capability level of the DSS01, DSS02, DSS03 subdomains had reached level 3 (Established Process). DSS05 and DSS06 sub-domains have reached level 4 (Predictable Process). The level of DSS capability to be achieved is level 5. Following the analysis, recommendations are given using COBIT 5 DSS domains to reach level 5 [7]. [6]. The similarity of this research lies in the research subject, namely IMISSU. This study's difference is assessing the performance of information technology at Udayana University using the COBIT Framework approach. The results of this study can be used as a comparison of the research results. 
Similar research is related to research conducted at IMISSU Udayana University, namely to evaluate the level of IMISSU service satisfaction and provide recommendations using the COBIT framework that focuses on the MEA domain (Monitor, Evaluate and Assess). The level of AEC capability to be achieved is level 4. The results show that the AEC capability level has not reached level 4 . The research provides recommendations for improving the AEC domain's performance [8]. This research was conducted on the same object, namely IMISSU, and the difference is in the assessment framework used, namely the COBIT Framework. The results of this study can be used as a comparison of the research results.

\subsection{E-readiness}

E-readiness is the readiness of a country, region, organization, or person to take advantage of information and communication technology to maintain prosperity and growth [9]. The results of a study by the Center for International Development conducted at Harvard University defined "e-readiness" as "readiness for world networks" [10]. E-readiness is also defined as the ability to pursue value creation opportunities by using the internet, which can be used as a measure to increase capabilities and capacities in the context of specific opportunities identified [11].

Assessment e-readiness is a tool used to find a country or institution's starting point in implementing a strategy that uses technology and to understand and identify opportunities for technological development [12]. Assessment e-readiness can reduce the change process for stakeholders to adopt technology and avoid failure.

There are many tools for assessing the level of e-readiness. Assessment tool ereadiness was first developed by the Computer Systems Policy Project in 1998. Since this development, many assessment tools e-readiness emerging from either research organizations, academia, business firms, or individuals. E-readiness assessment is very diverse in goals, strategies, and results and can be designed for macro and micro-level assessments [13]. Assessments often expect suggestions for improvements in specific components.

Assessment tool e-readiness intended to provide the best judgment about variables or components that affect the application of technology to help make decisions that decide what components to focus on and the extent to which improvements must be made to improve the overall application of technology [12].

\subsection{Integrated Information Systems}

Systems integration combines different and often incompatible technologies, applications, and data communications into a uniform information technology architecture and functioning work structure [14]. An integrated information system is a system that combines several information systems so that they can be connected and exchanging information. Integrated information systems consist of information systems and integration, which means several information systems or functional areas that carry out efforts or processes to build a single unit interconnected and exchange data. The purpose of integration in information systems is for efficiency and effectiveness in exchanging data and information flows.

\subsection{STOPE Framework}

Linstone method is the beginning of before being developed by Bakry to STOPE Framework. Linstone method consists of three domains: the domain Technology, domain Organization, and domain People, which then added two domains by Bakry, namely the domain Strategy and domain Environment [15]. 


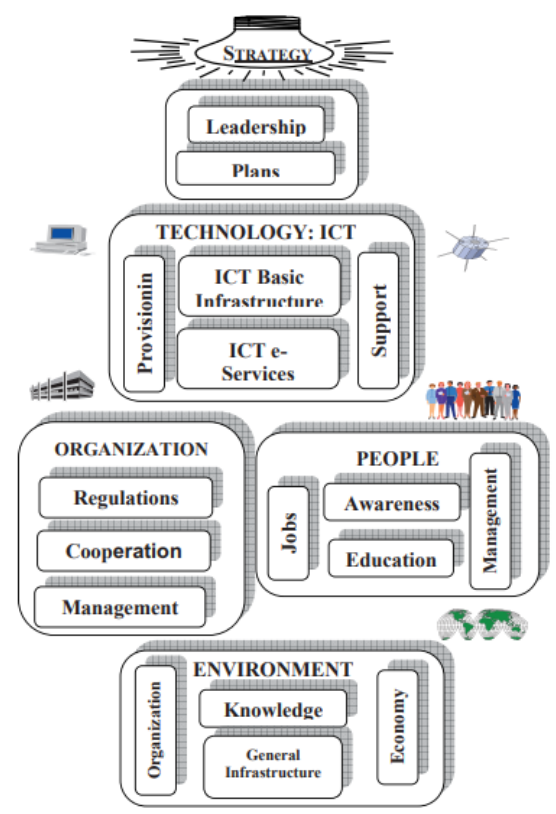

Figure 2. The STOPE Framework

Figure 2 is an overview of the STOPE framework, consisting of five main domains; it is further divided into sub-domains (issues). Sub-domains are further divided into sub-subdomains (factors).

\section{a) Domain Strategy}

Domain strategy discusses the direction or goals, commitments, and plans for developing and using ICT for the future. Domain strategy consists of two sub-domains (issues), namely the issue of leadership and the issue of development planning.

\section{b) Domain Technology}

Domain technology discusses the current status of information and communication technology facilities. The four related sub-domains are basic infrastructure, infrastructure $e$ service, provision, and support.

\section{c) Domain Organization}

Domain organization discusses the current status related to information and communication technology regulations and management. Three sub-domains are related to this domain: technology regulation, cooperation in technology between organizations, and technology management.

\section{d) Domain People}

Domain people or human resources, discussing the current status related to users and skills in using ICT. The four related sub-domains are awareness, education and training, qualifications and employment, and technology management.

\section{e) Domain Environment}

Domain environment discusses the current status related to surrounding nontechnology issues that affect the current state of Technology. The four sub-domains discussed are knowledge, economic resources, management and non-information, and communication technology infrastructure.

\subsection{Assessment E-readiness with STOPE Framework}

The use of the STOPE Framework in the e-readiness assessment covers three levels. Five main domains occupy the first level. The second level is the sub-domains, which are the 
main issues (issues) of the domain. The third level is the sub-sub-domain (factor), which is an issue originating from the sub-domain. At each level, two things are assessed: the value representing the condition of the domain, problem, or factor and the value of the level of importance that represents its influence.

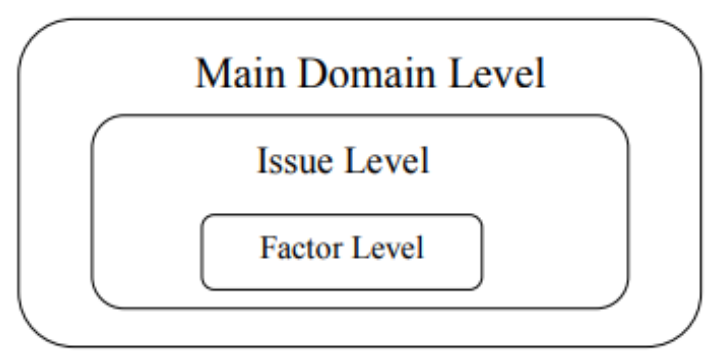

Figure 3. STOPE Framework Levels

Figure 3 is an illustration of the levels in the STOPE Framework. At the domain level, value is sought importance (i). At the issue and factor level, looking for value importance (i) and value measure $(m)$. Rating refers to a scale Likert. Score importance is in the range of values 0 4 or a scale of five values and values measured in the range of values $0-3$ or a scale of four values.

Table 1. Five Value Scale

\begin{tabular}{ccccc}
\hline 0 & 1 & 2 & 3 & 4 \\
\hline Not important & Quite important & Neutral & Important & Very Important \\
\hline
\end{tabular}

Table 1 is a five-value scale used to find value importance. Starting from number 0 is not important. The number 1 is of quite importance. The number 2 is neutral. The number 3 is important. The number 4 is very important.

Table 2. Four Value Scale

\begin{tabular}{c|c|c|c}
\hline 0 & 1 & 2 & 3 \\
\hline None & Bad & Average & Good \\
\hline
\end{tabular}

Table 2 is a four-value scale used to find values measure. Starting from number 0 is none. Number 1 is bad. Number 2 is average. Number 3 is good.

Assessment and ranking are carried out through at least six stages. Stage one is counting the measure of the factors. Stage two is counting the importance of the factors. Stage three is counting the measure of the issue by finding the factor weights first. Stage four is counting the importance of the issues. Stage five is counting the measure of the domain by finding the issue weight first. Stage six is counting importance from the domain and look for the domain weights.

\subsubsection{Domain Level Assessment}

Each of the five main domains is "indexed" and associated with "measure" and by "weight". Each primary domain can be assessed independently using the sub-domains associated with it. The main domain level assessment uses Formula 1.

domain weight $=\frac{\text { domain importance }}{\sum_{k=1}^{5} \text { domain importance }}$

Formula 1 is a formula to find the weight of the domain with the domain importance level divided by the average value of the domain importance level. 


\subsubsection{Issue Level Assessment}

Each of the five STOPE domains is considered to have several sub-domains, and each of these sub-domains is "indexed" and associated with "measure" and with "weight." Each subdomain can be assessed independently using the sub-domains associated with it. The issue or sub-domains level assessment uses Formula 2.

issue weight $=\frac{\text { issue importance }}{\sum_{k=1}^{n} \text { issue importance }}$.

Formula 2 is a formula to find the weight of the sub-domain. In order to obtain the subdomains weight, the importance of sub-domains is divided by the total importance of subdomain.

\subsubsection{Factor Level Assessment}

Each of the five STOPE domains is considered to have several sub-domains and the sub-domains have sub-domains or factors, and each of these sub-domains is "indexed" and associated with "measure" and with" weight." Each sub-domain can be assessed independently using the related sub-subdomains. Factor weight values are obtained by finding the average amount of the overall data obtained. The factor or sub-subdomains level assessment uses Formula 3.

factor weight $=\frac{\text { total number of measure values }}{\text { amount of data }}$

Formula 3 is a formula to find the weight of the sub-sub-domain. In order to obtain the factor weight, the importance of factor is divided by the total importance of factor.

\section{Result and Discussion}

4.1 Research Sample

Based on the Slovin sampling technique's calculation results with an error tolerance level of $10 \%$, the number of respondents is 100 . Questions are divided according to the status or position of the respondent by the related domain. Table 3 contains the distribution of the questionnaire.

Table 3. Respondent by Occupation

\begin{tabular}{ccll}
\hline Occupation & Total & Questionnaires Code & \multicolumn{1}{c}{ Explanation } \\
\hline USDI & 30 & Questionnaires I & $\begin{array}{l}\text { Respondents in the domain } \\
\text { of Strategy, Technology and } \\
\text { Organization }\end{array}$ \\
\hline Staff & 15 & Questionnaires II & $\begin{array}{l}\text { Respondents in the domain } \\
\text { of Organization, People and } \\
\text { Environment }\end{array}$ \\
\hline Lecturer & 15 & Questionnaires II & $\begin{array}{l}\text { Respondents in the domain } \\
\text { of Organization, People and } \\
\text { Environment }\end{array}$ \\
\hline Student & 40 & Questionnaires III & $\begin{array}{l}\text { Respondents in the domain } \\
\text { of People and Environment }\end{array}$ \\
\hline
\end{tabular}

Table 3 shows, it is known that the questionnaire is divided into 3 parts, questionnaire 1 for USDI, questionnaire 2 for staffs and lecturers, and questionnaire 3 for students. The distribution is based on statistics, namely to get valid results, a minimum of 30 samples is required for one part of the questionnaire. The selected respondents consisted of various positions adjusted to the questionnaire domain to make it more targeted. 


\subsection{Framework Modification}

In the application of this questionnaire, it must be modified to suit the case study being studied. Table 4 is the result of framework modifications that have been made to suit the case study. Issues and factors that are not related to case studies in educational institutions are eliminated and modified.

Table 4. Framework Modification Result

\begin{tabular}{|c|c|c|}
\hline No. & Domain & After Modification \\
\hline 1. & Strategy & $\begin{array}{c}\text { The factors of "Government Support", "HR Planning", and "Non- } \\
\text { IT Planning" were eliminated. }\end{array}$ \\
\hline 2. & Technology & $\begin{array}{l}\text { The "Organizational Planning" factor was modified. The } \\
\text { "Government" factor, "IT Provision" issue were eliminated. }\end{array}$ \\
\hline 3. & Organization & The issue of "IT regulation" were eliminated. \\
\hline 4. & People & The issue of "IT Training and Education" were eliminated. \\
\hline 5. & Environment & $\begin{array}{l}\text { The issues of "Knowledge", "Resources and Economy" were } \\
\text { eliminated. }\end{array}$ \\
\hline
\end{tabular}

\subsection{Assessment and Ranking}

\subsubsection{Sub-domain Assessment}

The assessment was carried out on 11 modified sub-domains (issues). The following are the results of the assessment and ranking at the sub-domain level.

Table 5. Sub-domain Asssessment

\begin{tabular}{ccccl}
\hline No & Issues & Measure & $\%$ & Explanation \\
\hline 1. & Leadership & 2,7 & $90 \%$ & Very ready \\
\hline 2. & Planning Development & 2,66 & $88,60 \%$ & Very ready \\
\hline 3. & Basic Infrastructure & 2,93 & $97,60 \%$ & Very ready \\
\hline 4. & ICT & 2,9 & $96,60 \%$ & Very ready \\
\hline 5. & E-service Infrastructure & 2,55 & $85 \%$ & Ready \\
\hline 6. & ICT support & 2,96 & $98,60 \%$ & Very ready \\
\hline 7. & Technology Cooperation & 2,71 & $90,30 \%$ & Very ready \\
\hline 8. & Management & 2,34 & $78 \%$ & Ready \\
\hline 9. & Information Technology & 2,15 & $71,60 \%$ & Ready \\
\hline 10. & Technology Awaraness & 2,28 & $76 \%$ & Ready \\
\hline 11. & Technology Satisfaction & 2,67 & $89 \%$ & Very Ready \\
\hline
\end{tabular}

Table 5 shows the results of the ratings for the sub-domain level. From the table, it can be concluded that many issues are in the very ready stage. The ready stage issue is technical support from the domain technology, information technology awareness, and satisfaction issues of the domain people, and management issues of the domain environment.

\subsubsection{Domain Assessment}

The assessment was carried out on five main domains that the assessor had carried out, starting from the factor level. The following are the results of the assessment and ranking at the domain level. 
Table 6. Domain Assessment

\begin{tabular}{ccccc}
\hline No & Domain & Measure & $\%$ & Explanation \\
\hline 1. & Strategy & 2,67 & $86,67 \%$ & Very Ready \\
\hline 2. & Technology & 2,79 & $93 \%$ & Very Ready \\
\hline 3. & Organization & 2,83 & $94,3 \%$ & Very Ready \\
\hline 4. & People & 2,24 & $74,66 \%$ & Ready \\
\hline 5. & Environment & 2,47 & $82,33 \%$ & Very ready \\
\hline & STOPE Overall & 2,60 & $86,66 \%$ & Very Ready \\
\hline
\end{tabular}

Table 6 is the result of the assessment and ranking for the domain level. From the table, the percentage is above $75 \%$. It can be concluded that 4 out of 5 domains are already at the very ready level, with a value domain people are at the ready level with a percentage value of $74.66 \%$.

\subsubsection{STOPE Assesment}

STOPE assessment is an assessment obtained from a combination of the five domains' values that represent the overall STOPE readiness value. The STOPE assessment and ranking can be seen in Table 6. Overall STOPE got a value of 2.60 which was converted into a percentage to be $86.66 \%$. From these results, Udayana University is already at a very ready stage in implementing the Integrated Information System.

\section{Conclusion}

The conclusions that can be drawn from this study are as follows:

1) Assessment e-readiness integrated information system at Udayana University using the modified STOPE framework. The modification results consisted of 5 domains, 11 subdomains and 14 factors and were converted into a questionnaire. 100 questionnaires were distributed with 30 pieces for employees in the information and communication technology department, 30 for administrative staff and 40 for students.

2) Based on the assessment results, domain people get the lowest result, namely $74.66 \%$ with ready status. Meanwhile, the other four domains are in a very ready status with domain values strategy $86.67 \%$, domain technology $93 \%$, domain organization $94.3 \%$, and domain environment $82.33 \%$. Recommendations are given on several weak points found, namely the technology and people.

\section{Reference}

[1] K. Schwab, The Global Competitiveness Report 2015-2016, World Economic Forum, Switzerland, 2015.

[2] B. J. W. Ellen F. Monk, Concepts on Enterprise Resource Planning (4th Edition), 4th ed., Boston: Course Technology, 2013.

[3] K. M. A. H. Abdulkader A. Alfantookh, Saad Haj Bakry, "Assessment Indicators for Information Technology in Higher Education Institutions A STOPE Approach," Asian Journal of Information Management 2 (1), 2008.

[4] H. Susanto, "Pendekatan Framework STOPE untuk Mengukur Kesiapan Pengalihan PBB pada Pemerintah Kabupaten Gunungkidul," Jurnal Nasional Teknik Elektro dan Teknologi Informasi, vol. 3, no. 2, pp. 103-108, 2014.

[5] W. M. H. Setyawan, W. W. Winarno, and E. T. Lutfhi, "Evaluasi Kesiapan Perguruan Tinggi Dalam Penerepan Sistem Informasi Akademik," Jurnal INFORMA Politeknik Indonusa Surakarta, vol. 1, no. 3, 2016.

[6] A. A. N. H. Susila, and E. Suryani, "The Suitability Evaluation Analysis of Lecturer Management Information System (SIMDOS) with User and Management Needs (Case Study: Udayana University)," in PROCEEDINGS OF INTERNATIONAL SEMINAR OF CONTEMPORARY RESEARCH IN BUSINESS AND MANAGEMENT, 2017.

[7] A. I. Saridewi, "Evaluasi IMISSU (Integrated Management Information Systems of Udayana University) menggunakan COBIT 5 Fokus Domain DSS," Electrical Engineering, Udayana University, Bali, 2018. 
[8] A. A. M. D. Krisnandari, D. M. Wiharta, and N. P. Sastra, "Penerapan Teknologi Informasi dalam Reformasi Birokrasi pada Bidang Pendidikan," Majalah IImiah Teknologi Elektro, vol. 18, no. 2, pp. 287-292, 2019.

[9] Seliger, "Handbook of Research on E-Government Readiness for Information and Service Exchange: Utilizing Progressive Information Communication Technologies," EGovernment Readiness for Information and Service Exchange, pp. 381-394, 2010.

[10] G. S. Kirkman, C. A. Osorio, and J. D. Sachs, The Networked Readiness Index: Measuring the Preparedness of Nations for the Networked World, 2002.

[11] V. Maugis, N. Choucri, S. E. Madnick et al., "Global e-Readiness for What? Readiness for e-Banking," Information Technology for Development, vol. 11, no. 4, pp. 313-342, 2005.

[12] V. Durek, and N. B. Redep, "Review on e-readiness assesment tools," Central European on Information and Intelligent Systems, pp. 161-168, 2016.

[13] S. M. Mutula, and P. v. Brakel, "An evaluation of e-readiness assessment tools with respect to information access: Towards an integrated information rich tool," International Journal of Information Management, vol. 26, no. 3, pp. 212-223, 2006.

[14] J. M. Myerson, Enterprise Systems Integration 2nd Edition, Boca Raton: Auerbach Publications, 2001.

[15] K. I. S. Al-Osaimi, "Mathematical Models for E-Readiness Assesment of Organizations with Intranet," King Saud University, 2007. 